\title{
Non Chemical Management Strategies for Control of Tomato Leaf Curl Virus
}

\author{
Nagamandla Ramya Sri* and Shantanu Jha \\ Bidhan Chandra Krishi Viswavidhyalaya, Faculty of agriculture, \\ Mohanpur, Nadia, West Bengal-741252, India \\ *Corresponding author
}

\begin{tabular}{|l|}
\hline Ke y w o r d s \\
$\begin{array}{l}\text { Non chemical } \\
\text { management, Leaf } \\
\text { curl virus, Tomato }\end{array}$ \\
\hline Article Info \\
\hline $\begin{array}{l}\text { Accepted: } \\
\text { 16 February } 2018 \\
\text { Available Online: } \\
\text { 10 March } 2018\end{array}$ \\
\hline
\end{tabular}

A B S T R A C T

\begin{abstract}
Tomato is native to Central and South America. It is a popular and versatile food ranking third in the world's vegetable production, next to potato and sweet potato and placing itself in first place among the processing crops. A wide range of insects attack tomato and forms major limiting factor in its successful cultivation and in improvement of yield. In addition to pests Viral diseases are also considered as a important factor which causes severe yield losses at most serious level. Vegetable cultivation is becoming more costly due to the increasing use of purchased inputs such as pesticides and fertilizers to sustain production level. These inputs are also a cause for concern due to their deleterious effect on human health and the environment so that the proposed research study was conducted during 2016-17 at Central Research Farm, BCKV. On Tomato (Moula F1 hybrid) on Non chemical Management strategies for control of tomato leaf curl virus. Results revealed that In the six different management systems $\mathrm{T}_{6}$ in which seedlings were grown under net in nursery followed by transplanting was done in poly house was more effective over rest of the treatments. After that T1 in which seedlings were grown under net in nursery followed by installation of yellow sticky trap 15DAT in main field. followed by T2 in which seedlings were grown under net in nursery without sticky trap in main field, T3 in which seedlings were grown in plug trays in nursery followed by yellow sticky trap 15DAT in main field, T4 in which seedlings were grown in plug trays in nursery without yellow sticky trap in main field, T5 control that is without any treatment. The percent disease incidence of leaf curl virus is 0 in T6. Which was followed by T1(18.33\%), T2(20.56\%), $\mathrm{T} 3(28.33 \%), \mathrm{T} 4(39.44 \%)$ and control T5(55\%).
\end{abstract}

\section{Introduction}

Tomato is native to Central and South America. It is a popular and versatile food ranking third in the world's vegetable production, next to potato and sweet potato and placing itself in first place among the processing crops. It is a cheap source of vitamin- $\mathrm{C}$ and minerals $\mathrm{A}$ wide range of insects attack tomato and forms major limiting factor in its successful cultivation and in improvement of yield. Among the various insects pest attacking tomato such as aphids (Aphis gossypii), thrips (Thrips tabaci) and whiteflies (Bemisia tabaci) act as a vector of many virus diseases. In addition to pests Viral 
diseases are also considered as a important factor which causes severe yield losses at most serious level. Tomato is susceptible to more than 200 diseases (Lukyanenko, 1991), out of which 40 are caused by viruses (Martelli and Quacquarelli, 1982). Among these viral diseases, Tomato leaf curl virus (TLCV) belonging to family Geminiviridae and genus Begomovirus is considered most devastating. A recent socio-economic survey ranked Tomato leaf curl virus (TLCV), transmitted by B. tabaci, as the most important disease causing virus of tomato (Chowda et al., 2004) Epidemics of Tomato leaf curl virus associated with upsurge of whiteflies (Bemisia tabacci) on tomato crop. This has been frequently reported with the yield losses up to $100 \%$. Vegetable cultivation is becoming more costly due to the increasing use of purchased inputs such as pesticides and fertilizers to sustain production level. These inputs are also a cause for concern due to their deleterious effect on human health and the environment. Therefore, an attempt has been made in the present study on Non chemical nursery management practices and using of yellow sticky traps in main field to control leaf curl virus.

\section{Materials and Methods}

Experiment was conducted at Central Research Farm, Gayeshpur, Bidhan Chandra Krishi Viswavidyalaya, Nadia, West Bengal. During December 2016 to March 2017 on tomato (Moula). Raised nursery seedbeds of 1 $\mathrm{m}$ wide were constructed on 25.10.2016 the seeds of tomato variety MOULA (F1 Hybrid) were sown and covered lightly with soil and watered lightly. Then one of the nursery bed was covered with insect proof net and other was left as such. An1d some seeds were sown in portray using coco-peat as growing media for seedling production. The trays were trapped gently to fill the cells properly and the seeds were sown the seedlings of 30 days old were ready to transplant. In the main field plot size is $4 \times 2 \mathrm{~m}$ and spacing adopted is $0.75 \times 0.70$ m. six different non chemical treatments including control was assessed against the leaf curl virus and its vector whitefly. Each treatment was replicated four times during the crop season observations were recorded for every 15 days. The population of white fly were counted as No. of adults/ five leaves and mean was produced. nymphs and adults of whitefly suck the sap from leaves which causes leaves to yellow and curl, and by the production of honeydew, which causes leaves to appear shiny or blackened (from sooty mold growing on the honeydew). These whiteflies transmit gemini viruses that cause tomato leaf curl, on visual method, symptom of damage and then leaf curl index/plant was worked out as per the method described by Lapidot et al., (2006) and observations were taken every 15 days interval from sowing to harvest and mean was worked out. At first the whitefly population is correlated with weather then correlation is done between whitefly and PDI. Data was interpreted by doing ANOVA and AUDP curve area under disease progression curve.

\section{Results and Discussion}

Correlation of whitefly with environment in open and poly house condition

Results revealed that maximum and average temperature, maximum, minimum and average relative humidity, average canopy temperature and light intensity exhibited significant positive correlation with whitefly population in open condition where as in poly house condition minimum and average relative humidity exhibited significant negative correlation. These findings are more or less confirmatory with Selvaraj and Ramesh (2012) reported that Whitefly population was build up showed a significant and positive correlation with maximum and minimum 
temperature whereas, it was significant and negative association with evening relative humidity.

\section{Correlation of PDI of leaf curl virus with white fly and effect of different treatments to manage leaf curl virus}

There was a significant positive correlation between percent disease incidence and white fly mean population as well as white fly trapped as mentioned in the (Table 3) these weather conditions are applicable to all the management treatments practiced in the main field. The efficacy of different non chemical treatments was evaluated against white fly and leaf curl virus from November to January of 2016-2017. Treatment in which seedlings were grown under net in nursery and transplanting was done in poly house was more effective over rest of the treatments. After that, Treatment one in which seedlings were grown under net in nursery followed by installation of yellow sticky trap 15DAT in main field was effective. followed by the treatment two in which seedlings were grown under net in nursery without sticky trap in main field, Treatment three in which seedlings were grown in plug trays in nursery followed by installation of yellow sticky trap 15DAT in main field, Treatment four in which seedlings were grown in plug trays in nursery without yellow sticky trap in main field and Treatment five control that is without any treatment. The percent disease incidence of leaf curl virus is 0 in T6. Which was followed by T1(5.32\%), $\mathrm{T} 2(7.30 \%), \quad \mathrm{T} 3(10.00 \%), \mathrm{T} 4(14.92 \%)$ and control T5(21.03\%).

Area under disease progression curve also shows that disease progression under such conditions was higher in control plot Treatment five Which was 1575 followed by T4 -1125.8, T3 -795.55, T2 -571.66, T1 491.66 and Treatment six which was zero. Where no disease was observed from this it is evident that T6 in which seedlings were grown under net in nursery followed by transplanting was done in poly house is most effective in which virus incidence was not seen. And in open field condition $\mathrm{T} 1$ is most effective in which seedlings were grown under net in nursery followed by yellow sticky trap in main field 15DAT. Statistical analysis also showed that there is a significant critical difference is present in between treatments. The present study is more or less significant with the studies of Ioannou and Iordanou. (1985) who reported that In glasshouse and low-tunnel crops in particular, leaf curl virus disease could be reduced, or even avoided completely Yaun licai et al., (2016) reported that covering insect net reduced the number of Bemisia tabaci (Gennadius) by $94.50 \%$, and the control effects on TY virus disease of autumn tomato varieties 'Xiangrui' and 'Tiandi No. 1' reached $76.0 \%$ and $100 \%$ respectively in plasticprotected cultivation. Moustafa et al., (1991) reported that covering the seedbed with insectproof muslin net cloth gave the best result followed by the use of yellow sticky traps erected around the uncovered nursery. Different non chemical management practices in nursery and main field against leaf curl virus and whitefly were evaluated to show a effective management system. In the six different management systems $\mathrm{T}_{6}$ in which seedlings were grown under net in nursery followed by transplanting was done in poly house was more effective over rest of the treatments. After that $\mathrm{T} 1$ in which seedlings were grown under net in nursery followed by installation of yellow sticky trap 15DAT in main field. Followed by T2 in which seedlings were grown under net in nursery without sticky trap in main field, T3 in which seedlings were grown in plug trays in nursery followed by yellow sticky trap 15DAT in main field, T4 in which seedlings were grown in plug trays in nursery without yellow sticky trap in main field, T5 control that is without any treatment. 
Table.1 Criteria for grading of TLCV disease

\begin{tabular}{|l|l|l|}
\hline S.NO & SYMPTOM & Response value \\
\hline 1. & No symptom & 0.00 \\
\hline 2. & 1-10 leaves per plant showing curling & 1.00 \\
\hline 3. & 10.1-20 leaves per plant showing curling & 3.00 \\
\hline 4. & 20.1-30 leaves per plant showing curling & 5.00 \\
\hline 5. & $\begin{array}{l}\text { 30.1-50 leaves per plant showing curling } \\
\text { 6. }\end{array}$ & 7.00 \\
\hline $\begin{array}{l}\text { 50.100 leaves per plant showing } \\
\text { curling }\end{array}$ & 9.00 \\
\hline
\end{tabular}

Table.2 Non chemical management schedules for control of whitefly and leaf curl virus disease of tomato

\begin{tabular}{|c|c|}
\hline treatment & Non chemical management practices for Nursery and main field \\
\hline $\mathbf{T}_{1}$ & $\begin{array}{l}\text { Growing of seedlings under net in nursery and installation of yellow sticky trap in } \\
\text { main field 15DAT. }\end{array}$ \\
\hline $\mathbf{T}_{2}$ & $\begin{array}{l}\text { Growing of seedlings under net in nursery without installation of yellow sticky trap } \\
\text { in main field }\end{array}$ \\
\hline$T_{3}$ & $\begin{array}{l}\text { Growing of seedlings in plug trays in nursery and installation of yellow sticky traps } \\
\text { in main field 15DAT. }\end{array}$ \\
\hline $\mathbf{T}_{4}$ & $\begin{array}{l}\text { Growing of seedlings in plug trays in nursery without any installation of yellow } \\
\text { sticky trap in main field. }\end{array}$ \\
\hline$T_{5}$ & Without any management practices \\
\hline$T_{6}$ & Growing of seedlings under net in nursery and transplanted in poly house \\
\hline
\end{tabular}

Table.3 Effect of different non chemical nursery and main field treatments to manage tomato leaf curl virus

\begin{tabular}{|l|l|l|l|l|l|l|r|r|r|}
\hline treatments & \multicolumn{1}{|c|}{ 09-Dec } & \multicolumn{1}{|r|}{ 23-Dec } & 07-Jan & 21-Jan & 04-Feb & 18-Feb & 01-Mar & MEAN & AUDPC \\
\hline T1 & $0.00(0.32)$ & $0.00(0.5)$ & $0.00(1.1)$ & $1.67(0.5)$ & $4.44(0.81)$ & $12.78(0.51)$ & $18.33(1.45)$ & $5.32(0.7)$ & 491.66 \\
\hline TRAPED & 0 & 6.5 & 16.25 & 8.5 & 10.2 & 27.5 & 17.5 & 46.6 & \\
\hline T2 & $0.00(0.25)$ & $0.00(0.67)$ & $2.22(0.72)$ & $5.00(0.67)$ & $8.89(1.1)$ & $14.44(1.3)$ & $20.56(1.65)$ & $7.30(0.91)$ & 571.66 \\
\hline T3 & $0.00(0.30)$ & $1.11(0.35)$ & $2.78(0.8)$ & $6.11(0.33)$ & $11.11(0.95)$ & $20.56(0.97)$ & $28.33(1.8)$ & $10.00(0.79)$ & 795.55 \\
\hline TRAPED & 0 & 5.25 & 10 & 7.5 & 9.8 & 28.25 & 19.25 & 52.11 & \\
\hline T4 & $0.00(0.35)$ & $0.55(0.65)$ & $4.44(0.45)$ & $11.11(0.44)$ & $20.00(1.65)$ & $28.89(1.87)$ & $39.44(2.5)$ & $14.92(1.13)$ & 1125.83 \\
\hline T5 & $0.00(1.45)$ & $2.78(0.44)$ & $6.67(0.42)$ & $15.00(0.99)$ & $26.67(0.75)$ & $40.56(3.2)$ & $55.00(3.75)$ & $21.03(1.43)$ & 1575 \\
\hline T6 & $0.00(1.25)$ & $0.00(0.43)$ & $0.00(0.82)$ & $0.00(1.1)$ & $0.00(0.85)$ & $0.00(1.00)$ & $0.00(1.6)$ & $0.00(0.85)$ & 0 \\
\hline CD@5\% & 0.00 & 11.76 & 16.14 & 13.266 & 15.37 & 14.78 & 21.25 & - & - \\
\hline Sem & 2.04 & 3.9 & 5.35 & 4.4 & 5.1 & 4.9 & 7.05 & - & -
\end{tabular}

*Figures in parenthesis are the mean values of white fly 
Int.J.Curr.Microbiol.App.Sci (2018) 7(3): 1795-1802

Table.4 Weekly average meteorological data of open field during crop period from December - March of 2016-2017

\begin{tabular}{|c|c|c|c|c|c|c|c|c|c|c|}
\hline SMW & $\begin{array}{l}\text { T - Maximum } \\
\left({ }^{\circ} \mathbf{C}\right)\end{array}$ & $\begin{array}{c}\text { T-Minimum } \\
\left({ }^{\circ} \mathrm{C}\right)\end{array}$ & $\begin{array}{c}\text { T-Average } \\
\left({ }^{\circ} \mathrm{C}\right)\end{array}$ & $\begin{array}{c}\text { Relative } \\
\text { humidity } \\
\text { Maximum } \\
(\%)\end{array}$ & $\begin{array}{c}\text { Relative } \\
\text { humidity } \\
\text { minimum } \\
(\%)\end{array}$ & $\begin{array}{c}\text { Relative } \\
\text { humidity } \\
\text { Average } \\
(\%)\end{array}$ & $\begin{array}{c}\text { Canopy } \\
\text { Temperature } \\
\left({ }^{\circ} \mathrm{C}\right)\end{array}$ & $\begin{array}{c}\text { Light } \\
\text { intensity } \\
(100 l u x\end{array}$ \\
\hline 48 & 29.36 & 16.57 & 22.96 & 93.00 & 58.29 & 75.64 & 29.70 & 512.00 & 4.7 \\
\hline 49 & 27.76 & 14.99 & 21.37 & 93.71 & 57.00 & 75.36 & 28.00 & 497.00 & 7.7 \\
\hline 50 & 25.30 & 10.80 & 18.05 & 94.14 & 54.57 & 74.36 & 26.20 & 469.00 & 7.3 \\
\hline 51 & 25.93 & 12.43 & 19.18 & 92.00 & 57.86 & 74.93 & 27.00 & 480.00 & 3.9 \\
\hline 52 & 25.49 & 13.43 & 19.46 & 95.75 & 66.13 & 80.94 & 26.50 & 476.00 & 2.7 \\
\hline 1 & 25.67 & 12.41 & 19.05 & 94.86 & 57.14 & 76.00 & 27.75 & 486.00 & 5.5 \\
\hline 2 & 24.13 & 10.59 & 17.35 & 91.00 & 47.29 & 69.14 & 26.30 & 476.00 & 5.9 \\
\hline 3 & 26.29 & 8.80 & 17.55 & 90.00 & 43.29 & 66.64 & 28.50 & 420.00 & 7.7 \\
\hline 4 & 27.66 & 11.81 & 19.75 & 90.00 & 50.43 & 70.21 & 29.45 & 560.00 & 6.6 \\
\hline 5 & 26.88 & 12.61 & 19.75 & 91.00 & 53.20 & 72.10 & 27.40 & 552.00 & 7.0 \\
\hline 6 & 27.40 & 13.47 & 20.44 & 90.30 & 41.00 & 65.65 & 29.87 & 555.00 & 8.8 \\
\hline 7 & 29.05 & 14.70 & 21.88 & 89.83 & 43.83 & 66.83 & 30.20 & 650.00 & 5.6 \\
\hline 8 & 30.25 & 16.00 & 23.13 & 88.57 & 44.28 & 66.43 & 33.37 & 675.00 & 5.9 \\
\hline 9 & 31.08 & 17.18 & 24.13 & 91.28 & 47.00 & 69.14 & 33.43 & 760.00 & 8.8 \\
\hline 10 & 32.00 & 23.00 & 27.50 & 89.00 & 46.00 & 67.50 & 31.84 & 860.00 & 4.6 \\
\hline
\end{tabular}

Table.5 Weekly average meteorological data of poly house during crop period from December - March of 2016-2017

\begin{tabular}{|c|c|c|c|c|c|c|c|c|}
\hline SMW & $\begin{array}{c}\text { T - Maximum } \\
\left({ }^{\circ} \mathrm{C}\right)\end{array}$ & $\begin{array}{c}\text { T-Minimum } \\
\left({ }^{\circ} \mathrm{C}\right)\end{array}$ & $\begin{array}{c}\text { T-Average } \\
\left({ }^{\circ} \mathrm{C}\right)\end{array}$ & $\begin{array}{c}\text { Relative } \\
\text { humidity } \\
\text { Maximum } \\
(\%)\end{array}$ & $\begin{array}{c}\text { Relative } \\
\text { humidity } \\
\text { minimum } \\
(\%)\end{array}$ & $\begin{array}{c}\text { Relative } \\
\text { humidity } \\
\text { Average } \\
(\%)\end{array}$ & $\begin{array}{c}\text { Canopy } \\
\text { Temperature } \\
\left({ }^{\circ} \mathrm{C}\right)\end{array}$ & $\begin{array}{c}\text { Light } \\
\text { intensity } \\
(100 l u x)\end{array}$ \\
\hline 48 & 29.36 & 16.57 & 22.96 & 93.00 & 58.29 & 75.64 & 29.70 & 512.00 \\
\hline 49 & 27.76 & 14.99 & 21.37 & 93.71 & 57.00 & 75.36 & 28.00 & 497.00 \\
\hline 50 & 25.30 & 10.80 & 18.05 & 94.14 & 54.57 & 74.36 & 26.20 & 469.00 \\
\hline 51 & 25.93 & 12.43 & 19.18 & 92.00 & 57.86 & 74.93 & 27.00 & 480.00 \\
\hline 52 & 25.49 & 13.43 & 19.46 & 95.75 & 66.13 & 80.94 & 26.50 & 476.00 \\
\hline 1 & 25.67 & 12.41 & 19.05 & 94.86 & 57.14 & 76.00 & 27.75 & 486.00 \\
\hline 2 & 24.13 & 10.59 & 17.35 & 91.00 & 47.29 & 69.14 & 26.30 & 476.00 \\
\hline 3 & 26.29 & 8.80 & 17.55 & 90.00 & 43.29 & 66.64 & 28.50 & 420.00 \\
\hline 4 & 27.66 & 11.81 & 19.75 & 90.00 & 50.43 & 70.21 & 29.45 & 560.00 \\
\hline 5 & 26.88 & 12.61 & 19.75 & 91.00 & 53.20 & 72.10 & 27.40 & 552.00 \\
\hline 6 & 27.40 & 13.47 & 20.44 & 90.30 & 41.00 & 65.65 & 29.87 & 555.00 \\
\hline 7 & 29.05 & 14.70 & 21.88 & 89.83 & 43.83 & 66.83 & 30.20 & 650.00 \\
\hline 8 & 30.25 & 16.00 & 23.13 & 88.57 & 44.28 & 66.43 & 33.37 & 675.00 \\
\hline 9 & 31.08 & 17.18 & 24.13 & 91.28 & 47.00 & 69.14 & 33.43 & 760.00 \\
\hline 10 & 32.00 & 23.00 & 27.50 & 89.00 & 46.00 & 67.50 & 31.84 & 860.00 \\
\hline
\end{tabular}


Table.6 Correlation coefficient (r) of whitefly population with weather parameters in open and poly house condition

\begin{tabular}{|c|c|c|c|}
\hline \multicolumn{2}{|c|}{ Environmental parameter } & OPEN & POLY HOUSE \\
\hline \multirow{2}{*}{ Temperature ${ }^{0} \mathrm{C}$} & Maximum & $0.642^{*}$ & 0.375 \\
& Minimum & 0.434 & 0.114 \\
\hline & Average & $0.554^{*}$ & 0.245 \\
\hline Relative Humidity (\%) & Maximum & $-.0 .632^{*}$ & -0.486 \\
\cline { 2 - 4 } & Minimum & $-.0 .590^{*}$ & $-0.721^{* *}$ \\
\cline { 2 - 4 } & Average & $-.0 .614^{*}$ & $-0.702^{* *}$ \\
\hline BSS & (Hr) & $0.312^{* *}$ & - \\
\hline Canopy temperature & Average & $0.728^{* *}$ & 0.168 \\
\hline Light intensity & Average & $0.814^{* *}$ & 0.513 \\
\hline
\end{tabular}

*Significant at $5 \%$ level of significance $* *$ Significant at $1 \%$ level of significance

Table.7 Correlation of PDI of leaf curl virus with white fly in all treatments

\begin{tabular}{|l|l|l|l|l|l|l|}
\hline & & & PDI & & & \\
\hline treatments & T1 & T2 & T3 & T4 & T5 & T6 \\
\hline $\begin{array}{l}\text { White fly } \\
\text { mean }\end{array}$ & $0.556 *$ & $0.951 * *$ & $0.900 * *$ & $0.954 *$ & $0.934 *$ & - \\
\hline $\begin{array}{l}\text { White fly } \\
\text { trapped }\end{array}$ & $0.828 * *$ & - & $0.603 *$ & - & & - \\
\hline
\end{tabular}

*Significant at $5 \%$ level of significance **Significant at $1 \%$ level of significance

Plate.1 Field at Central Research Farm of Bidhan Chandra Krishi Viswavidyalaya, Gayeshpur,

Nadia, West Bengal, leaf curl virus symptom
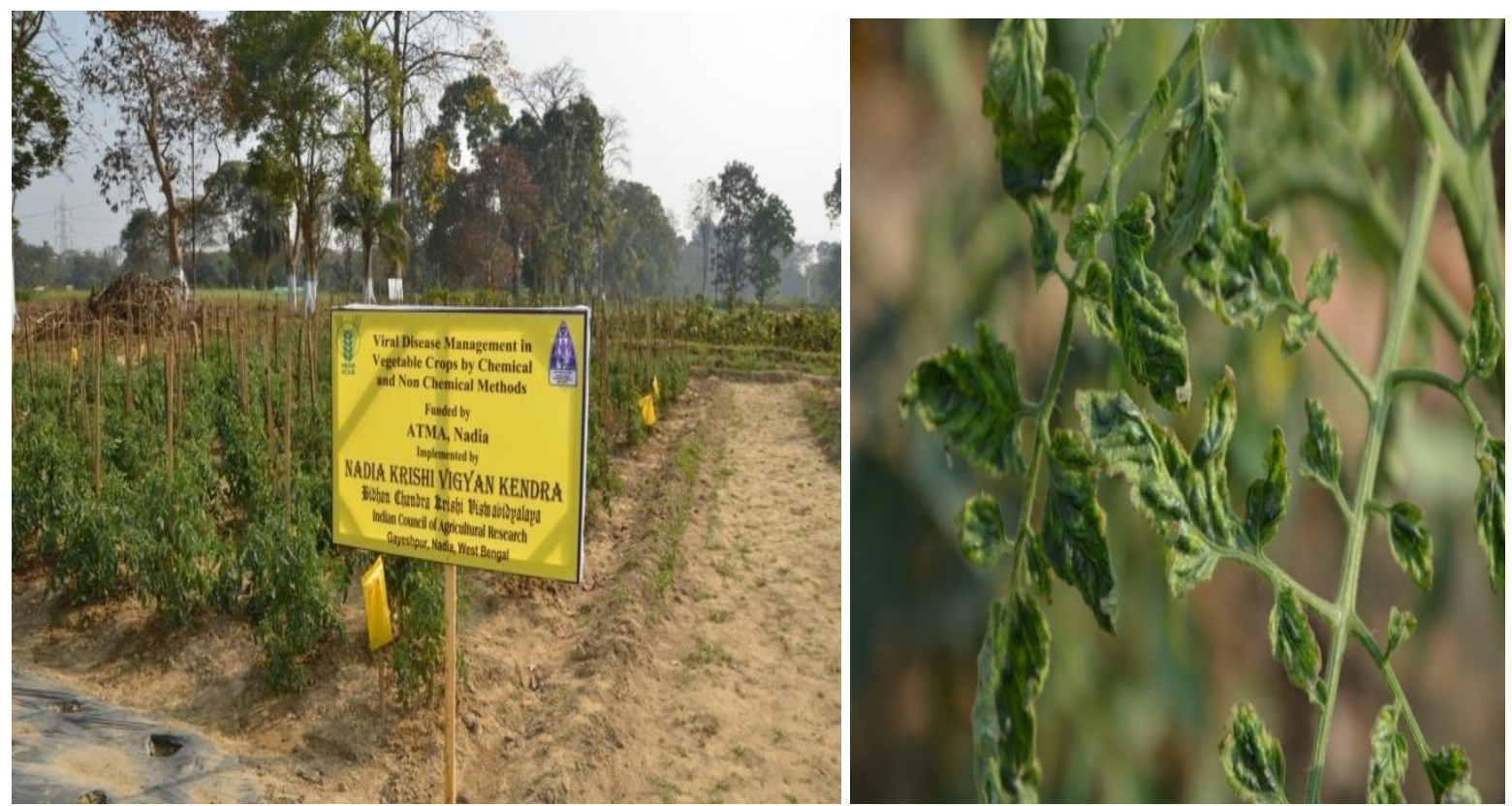
Fig.1 Incidence of leaf curl virus during december to march of 2016-2017 in six treatments

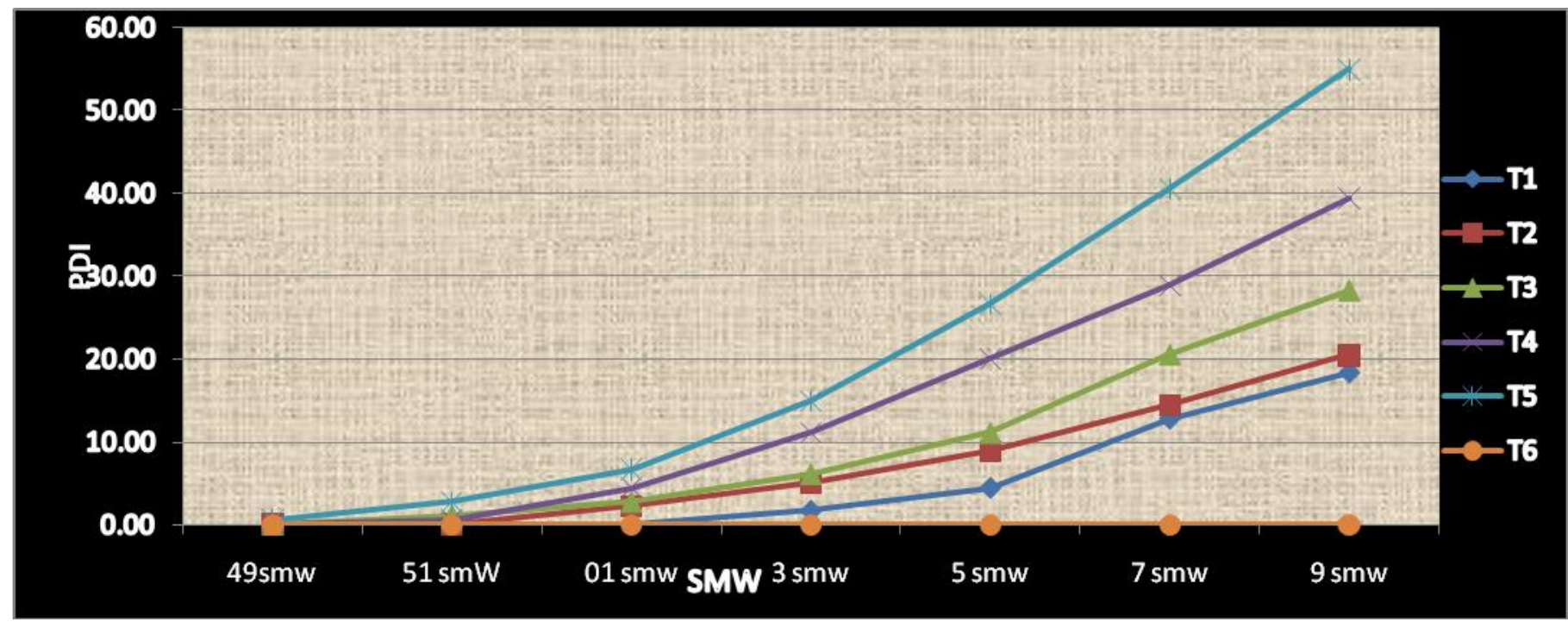

The percent disease incidence of leaf curl virus is 0 in T6. Which was followed by T1(18.33\%), T2(20.56\%), T3(28.33\%), T4(39.44\%) and control T5(55\%) (Fig. 1 and Table 1-7).

\section{Acknowledgement}

First and foremost I would like to thank the Almighty god for giving me this opportunity. I feel unfathomable euphoria to pronounce my Heartful veneration and gratitude to Prof. S. Jha, Department of agricultural Entomology, BCKV. I further extend my sincere gratitude to Dr. S. Dutta, Department of Plant Pathology and Dr. A. Saha Department of Agricultural Meterology and physics for providing their sincere guidance, keen interest, inestimable inspiration and valuable suggestions throughout the course of investigation.

I further extend my sincere thanks to Mrs. Malabika Chakraborty SMS of plant protection at KVK Nadia for helping me in analysis and research work in collection and compilation of data. Last but not least I want to thank all my friends who helped and encouraged me in conducting my research work from starting to end of work.

\section{References}

Ioannou, N. and Iordanou, N. (1985). Epidemiology of tomato yellow leaf curl virus in relation to the population density of its whitefly vector, Bemisia tabaci (Gennadius). Technical Bulletin, Agricultural Research Institute, Cyprus.71:7.

Lapidot, M. Ben-Joseph, R. Cohen, L. Machbash, Z. and Levy, D. (2006) Development of a Scale for Evaluation of Tomato yellow leaf curlvirus Resistance Level in Tomato Plants. American Phytopathological Society, 96(12):1404-1408

Lukyanenko, A.N. (1991) Disease Resistance in tomato. Springer Verlag, Berlin Heidelberg

Martelli, G.P. and Quacquarelli, A. (1982). The present status of tomato and pepper viruses. Acta Horticulturae, 127: 39-64.

Moustafa, S. S., Nakhla, M. K, Fadl, F. A. And El-Safty, N. (1991). Effect of nursery treatments on the control of tomato yellow leaf curl virus disease. Egyptian Journal of Agricultural Research.69(3):807-820. 
Selvaraj, S. and Ramesh, V. (2012). Seasonal abundance of whitefly, Bemisia tabaci Gaennadius and their relation to weather parameters in cotton. International Journal of Food, Agriculture and Veterinary Sciences, 2(3): 57-63.
Yuan Li Cai., Guo Wei Li, Wang Guang Yin, and Wang Sheng Nan. (2016). Effects of several prevention and control measures on tomato yellow leaf curl virus disease of plastic-protected autumn tomato. Journal of Henan Agricultural Sciences.45 (11):76-81.

\section{How to cite this article:}

Nagamandla Ramya Sri and Shantanu Jha. 2018. Non Chemical Management Strategies for Control of Tomato Leaf Curl Virus. Int.J.Curr.Microbiol.App.Sci. 7(03): 1795-1802. doi: https://doi.org/10.20546/ijcmas.2018.703.211 